Volume 15, No. 2, Juli 2018

\title{
PENGARUH WAKTU KONTAK AIR JERUK NIPIS (Citrus aurantifolia Swingle) TERHADAP PENINGKATAN KUALITAS KEBERSIHAN PIRING
}

\author{
Puja Krisnawati, Isnawati, Darmiah \\ Poltekkes Kemenkes Banjarmasin Jurusan Kesehatan Lingkungan \\ Jl. H. Mistar Cokrokusumo No. 1A Banjarbaru Kalimantan Selatan 70714 \\ Email: krisnawatipuja@yahoo.co.id
}

\begin{abstract}
Influence Of Contact Time Of Lime Juice (Citrus aurantifolia Swingle) On Improving The Quality Of Plate Hygiene. Equipment potential as food contamination is not clean enough and not appropriate washing process, because skip disinfection stage. One of disinfection process is by giving lime juice (Citrus aurantifolia Swingle)10\%. The purpose of this study was to determine the effectiveness of contact time of lime juice (Citrus aurantifolia Swingle) on improving the quality of plate hygiene. This study used experimental methode, data analysis was using Paired Sample T-Test and One Way Anova. The data was obtained by trial soaking plate in lime juice (Citrus aurantifolia Swingle) 10\% at contact time 1, 1,5 and 2 minutes. The result laboratory that the number of germs posttreatment was smaller than pre-treatment. E. coli on pre-treatment and post-treatment was negative. The contact time at 2 minutes could reduce the number of germs of $89,48 \%$. The Effective time on reduce the number of germs is 2 minutes and have qualify. It is suggested to the public to do the disinfection process by lime juice at least 2 minutes. To facilitate the use in the community researcher further can make concentration controller of lime juice $10 \%$.
\end{abstract}

Keyword: Lime Juice (Citrus aurantifolia Swingle); disinfection

\begin{abstract}
Abstrak: Pengaruh Waktu Kontak Air Jeruk Nipis (Citrus aurantifolia Swingle) Terhadap Peningkatan Kualitas Kebersihan Piring. Peralatan yang dapat mengkontaminasi makanan adalah peralatan yang tidak bersih akibat proses pencucian kurang sempurna karena tidak melakukan tahapan desinfeksi. Salah satu cara desinfeksi adalah pemberian air jeruk nipis (Citrus aurantifolia Swingle) 10\%. Tujuan penelitian ini adalah untuk mengetahui waktu kontak air jeruk nipis (Citrus aurantifolia Swingle) yang efektif dalam meningkatkan kualitas kebersihan piring makan. Penelitian ini menggunakan metode eksperimen, analisis data menggunakan uji Paired Sample T-Test dan uji One Way Anova., data diperoleh melalui uji coba perendaman piring dalam air jeruk nipis (Citrus aurantifolia Swingle) 10\% pada waktu kontak 1, 1,5 dan 2 menit. Hasil pemeriksaan di laboratorium angka kuman setelah perlakuan lebih kecil dari sebelum perlakuan. E. coli sebelum dan sesudah perlakuan hasilnya negatif. Pada waktu kontak 2 menit mampu menurunkan angka kuman sebesar $89,48 \%$. Waktu kontak yang efektif menurunkan angka kuman adalah 2 menit dan sudah memenuhi persyaratan. Disarankan kepada masyarakat melakukan proses desinfeksi menggunakan air jeruk nipis minimal 2 menit. Untuk memudahkan penggunaan di masyarakat peneliti selanjutnya dapat membuat alat pengatur konsentrasi larutan air jeruk nipis 10\%.
\end{abstract}

Kata kunci: Air Jeruk Nipis (Citrus aurantifolia Swingle); Desinfeksi

\section{PENDAHULUAN}

Kontaminasi yang terjadi pada makanan dan minuman dapat menjadi media penularan penyakit. Di negara maju diperkirakan $1 / 3$ dari populasi terinfeksi penyakit bawaan makanan[1]. Salah satu penyakit bawaan makanan (Food-borne disease) adalah keracunan yang diakibatkan dari makanan yang terkontaminasi. Di
Indonesia selama tahun 2013, telah tercatat 48 kejadian luar biasa (KLB) keracunan pangan yang berasal dari 34 Provinsi, terdiri dari 1.690 orang sakit dan 12 orang meninggal dunia. Jenis pangan penyebab KLB keracunan pangan tahun 2013 adalah masakan rumah tangga sebanyak $47,92 \%$, dan pangan jasa boga sebanyak $16,67 \%{ }^{[2]}$. 
Diperkirakan sekitar $80 \%$ penyakit bawaan makanan atau keracunan makanan disebabkan oleh adanya kontaminasi mikroba yang salah satunya berasal dari peralatan yang digunakan[3]. Alat makan merupakan salah satu faktor yang memegang peranan dalam menularkan penyakit, sebab alat makan yang tidak bersih dapat mengandung mikroorganisme yang menularkan penyakit lewat makanan, sehingga proses pencucian alat makan sangat berarti dalam membersihkan sisa makanan dari peralatan yang menyokong pertumbuhan mikroorganisme dan melepaskan mikroorganisme yang hidup[4].

Proses desinfeksi pada peralatan makan penting dilakukan dalam meningkatkan kualitas kebersihan pada peralatan makan, seperti desinfeksi secara fisik, kimia dan alami. Desinfeksi secara fisik seperti penggunaan air panas dengan suhu $82^{\circ} \mathrm{C}$ selama 2 menit dan suhu $100^{\circ} \mathrm{C}$ selama 1 menit. Desinfeksi secara kimia, yaitu dengan pemberian zat aktif chlor (konsentrasi 50 ppm) dan desinfektan alami seperti jeruk nipis (Citrus aurantifolia Swingle) yang memiliki kandungan seperti asam sitrat, minyak atsiri, saponin dan flavonoid yang bersifat sebagai antibakteri.

Berdasarkan hasil penelitian yang dilakukan oleh Apriyati Ningsih Tahun 2015 tentang pengaruh pemakaian perasan jeruk nipis sebagai desinfektan terhadap jumlah angka kuman bahwa konsentrasi air jeruk nipis (Citrus aurantifolia Swingle) yang efektif dalam menurunkan angka kuman adalah 10\% dengan kontak waktu 1 menit. Pada penelitian tersebut angka kuman masih berada di atas standar yaitu 3.006 koloni $/ \mathrm{cm}^{2}$, oleh karena itu maka dilakukan penelitian untuk penyempurnaan dari penelitian sebelumnya yaitu menambahkan variasi waktu kontak larutan air jeruk nipis (Citrus aurantifolia Swingle) yang menggunakan konsentrasi efektif sebesar $10 \%$ di Pujasera Banjarbaru.

\section{BAHAN DAN CARA PENELITIAN}

Jenis penelitian ini adalah eksperimen. Penelitian dilakukan dengan menggunakan desinfektan alami berupa air jeruk nipis (Citrus aurantifolia Swingle) dengan konsentrasi 10\%. Proses desinfeksi dilakukan dengan merendam piring dalam air yang ditambahkan air jeruk nipis $10 \%$ dengan variasi waktu kontak 1 menit, 1,5 menit dan 2 menit.

Desain penelitian yang digunakan yaitu dengan cara pretest postest with control group yaitu pengelompokkan anggota-anggota kelompok kontrol dan kelompok eksperimen dilakukan berdasarkan acak atau random. ${ }^{[5]}$ Rancangan penelitian ini dengan pengambilan sampel sebelum dan sesudah perlakuan desinfeksi menggunakan air jeruk nipis nipis (Citrus aurantifolia Swingle) pada waktu kontak 1 menit, 1,5 menit dan 2 menit sebanyak 4 kali pengulangan.

Populasi dari penelitian ini adalah semua pedagang yang melakukan proses pencucian dengan perendaman di Pujasera Banjarbaru. Sampel yang diambil berjumlah 1 pedagang yaitu "Warung Nasi Goreng Pa' Arif" karena makanan yang dijual bervariasi seperti nasi goreng, nasi mawut, mie goreng dan soto lamongan. Sampel yang diambil berupa piring karena kontak langsung dengan makanan dan berpotensi terhadap kontaminasi makanan.

Data yang diperoleh di entry dan dianalisis menggunakan uji Paired Sample T-Test untuk mengetahui perbedaan angka kuman sebelum dan sesudah perlakuan. Uji one way anova digunakan untuk mengetahui perbedaan dari variasi waktu kontak 1 menit, 1,5 menit dan 2 menit terhadap penurunan angka kuman sesudah didesinfeksi menggunakan air jeruk nipis nipis (Citrus aurantifolia Swingle) $10 \%$.

\section{HASIL DAN PEMBAHASAN}

Hasil observasi proses pencucian di Warung Nasi Goreng Pa' Arif Pujasera Banjarbaru, proses pencucian dilakukan dengan perendaman pada ember yang berjumlah 2 buah. Proses pencucian tidak melakukan tahap desinfeksi dan menggunakan lap yang dipakai secara berulang. Sumber air yang digunakan adalah air PDAM dengan suhu air $27^{\circ} \mathrm{C}$ dan $\mathrm{pH}$ air 5 
sedangkan pH air setelah dtambahkan air jeruk nipis nipis (Citrus aurantifolia Swingle) 10\% turun menjadi 3.

Perbedaan Angka Kuman Sebelum dan Sesudah Desinfeksi Menggunakan Air Jeruk Nipis (Citrus aurantifolia Swingle)

Rata-rata angka kuman sebelum dilakukan proses desinfeksi menggunakan larutan air jeruk nipis (Citrus aurantifolia Swingle) konsentrasi $10 \%$ pada sampel piring makan adalah berkisar antara 1.886-773 koloni/ $\mathrm{cm}^{2}$ dan rata-rata angka kuman pada kontrol (0 menit) adalah $1.083 \mathrm{koloni} / \mathrm{cm}^{2}$. Hasil pemeriksaan angka kuman dapat dilihat pada tabel 1 berikut.

Tabel 1. Perbedaan Angka Kuman Sebelum dan Sesudah Desinfeksi

\begin{tabular}{lccccc}
\hline \multicolumn{1}{c}{ Kode Piring } & \multicolumn{3}{c}{ Angka Kuman (Koloni/cm²) Pada } & Rata-Rata Angka \\
& \multicolumn{3}{c}{ Pengulangan } & Kuman \\
& I & II & III & IV & (Koloni/cm ${ }^{2}$ ) \\
\hline Kontrol (0 Menit) & 598 & 3.038 & 266 & 428 & 1.083 \\
SB 1 Menit & 614 & 1.038 & 750 & 919 & 830 \\
SB 1,5 Menit & 3.750 & 1.038 & 2.000 & 755 & 1.886 \\
SB 2 Menit & 1.575 & 1.125 & 219 & 171 & 773 \\
SD 1 Menit & 369 & 375 & 400 & 294 & 360 \\
SD 1,5 Menit & 2.200 & 265 & 485 & 371 & 830 \\
SD 2 Menit & 50 & 90 & 60 & 6 & 52 \\
\hline
\end{tabular}

Berdasarkan tabel 1. rata-rata angka kuman pada sampel usap alat piring makan sesudah diberi perlakuan desinfeksi menggunakan larutan air jeruk nipis (Citrus aurantifolia Swingle) konsentrasi $10 \%$ dengan waktu kontak 1 menit, 1,5 menit dan 2 menit berkisar antara 830-52 koloni/ $\mathrm{cm}^{2}$.

Angka kuman setiap perlakuan berbeda-beda. Hal ini dikarenakan beberapa faktor seperti piring yang digunakan untuk menyajikan makanan yang berbeda seperti nasi goreng, mie goreng, nasi mawut, kerupuk yang banyak mengandung lemak/minyak, protein dan karbohidrat. Piring yang digunakan untuk mewadahi kerupuk memiliki kandungan lemak/minyak berbeda dengan piring yang digunakan untuk menyajikan nasi goreng, mie goreng dan nasi mawut yang banyak mengandung lemak/minyak, protein dan karbohidrat. Faktor lain seperti kondisi awal piring atau tingkat kekotoran piring juga dapat berpengaruh terhadap angka kuman.

Berdasarkan hasil penelitian angka kuman sebelum perlakuan perlakuan pada waktu kontak 1 menit dan 1,5 menit dan 2 menit melebih standar yaitu $>100$ koloni/ $\mathrm{cm}^{2}$. Faktor yang mempengaruhi salah satunya adalah proses pencucian yang kurang tepat. Penggunaan air untuk proses perendaman mengandung minyak dari hasil pencucian piring sebelumnya sehingga kondisi piring menjadi sedikit berminyak. Penggunaan sabun cair dan alat penggosok yang cukup kotor akibat terkena kotoran yang menempel di piring sehingga proses pencucian tidak optimal. Air yang digunakan untuk membilas piring terdapat sisa sabun dari proses pencucian sebelumnya karena penggantian air setelah 3 kali pakai atau lebih sehingga dapat menurunkan kualitas kebersihan setelah pencucian.

Selain faktor tersebut tingginya angka kuman disebabkan proses pencucian tidak menggunakan air mengalir dan hanya menggunakan 2 bak pencucian. Menurut Permenkes No. 304 Tahun 1989 tentang persyaratan kesehatan rumah makan dan restoran bahwa bak pencucian sedikitnya terdiri dari 3 bilik/bak pencuci yaitu mengguyur, menyabun dan membilas. Lap yang digunakan untuk membersihkan piring setelah dikeringkan dipakai secara berulang sehingga dapat menyebabkan kontaminasi sekunder setelah pencucian. Berdasarkan uji Paired Sample TTest bahwa terdapat perbedaan yang signifikan antara angka kuman sebelum 
dengan sesudah perlakuan. Berdasarkan uji statistik menunjukkan bahwa larutan air jeruk nipis (Citrus aurantifolia Swingle) konsentrasi $10 \%$ terbukti mampu menurunkan jumlah angka kuman pada piring makan. Hal ini disebabkan karena adanya kandungan antibakteri dalam air jeruk nipis seperti flavonoid, saponin dan minyak atsiri.

Mekanisme kerja flavonoid sebagai antibakteri adalah membentuk senyawa kompleks dengan protein ekstraseluler dan terlarut sehingga dapat merusak memban sel bakteri[6]. Flavonoid juga dapat mendepolarisasi membran sel dan menghambat sintesis DNA, RNA maupun protein ${ }^{7]}$.

Mekanisme kerja saponin sebagai antibakteri adalah menurunkan tegangan permukaan sehingga mengakibatkan naiknya permeabilitas atau kebocoran sel bakteri dan diikuti dengan keluarnya senyawa intraseluler. Selain itu Jeruk nipis (Citrus aurantifolia Swingle) merupakan tanaman penghasil minyak atsiri sebagai suatu substansi alami yang memiliki efek antibakteri[8].

Keberadaan E. Coli Sebelum dan Sesudah Perlakuan dapat dilihat pada tabel 2 berikut:

Tabel 2. Keberadaan E. coli Pada Piring Makan Sebelum dan Sesudah Desinfeksi

\begin{tabular}{lllll}
\hline \multirow{2}{*}{ Kode Piring } & \multicolumn{4}{c}{ Angka Kuman (Koloni/cm²) Pada Pengulangan } \\
& I & II & III & IV \\
\hline Kontrol (0 Menit) & Negatif $(-)$ & Negatif $(-)$ & Negatif $(-)$ & Negatif $(-)$ \\
SB 1 Menit & Negatif $(-)$ & Negatif $(-)$ & Negatif $(-)$ & Negatif $(-)$ \\
SB 1,5 Menit & Negatif $(-)$ & Negatif $(-)$ & Negatif $(-)$ & Negatif $(-)$ \\
SB 2 Menit & Negatif $(-)$ & Negatif $(-)$ & Negatif $(-)$ & Negatif $(-)$ \\
SD 1 Menit & Negatif $(-)$ & Negatif $(-)$ & Negatif $(-)$ & Negatif $(-)$ \\
SD 1,5 Menit & Negatif $(-)$ & Negatif $(-)$ & Negatif $(-)$ & Negatif $(-)$ \\
SD 2 Menit & Negatif $(-)$ & Negatif $(-)$ & Negatif $(-)$ & Negatif $(-)$ \\
\hline
\end{tabular}

Berdasarkan tabel 2. keberadaan $E$. coli negatif (-) karena sumber air yang digunakan untuk proses pencucian adalah PDAM. Air PDAM sudah melalui tahapan proses pengolahan seperti proses desinfeksi dengan menambahkan chlor/kaporit. Desinfeksi ini berfungsi untuk membunuh kuman yang ada dalam air yang digunakan oleh PDAM. Oleh karena itu, hasil pemeriksaan E. coli sebelum perlakuan negatif (-).

Perbedaan Penurunan Angka Kuman Sesudah Perlakuan Menggunakan Larutan Air Jeruk Nipis (Citrus aurantifolia Swingle)

Persentase penurunan angka kuman sesudah di beri pelakuan desinfeksi menggunakan larutan air jeruk nipis $10 \%$ berkisar antara $39,90 \%$ 96,83\%. Persentase penurunan angka kuman pada waktu kontak 1 menit, yaitu sebesar 54,61\%, waktu kontak 1,5 menit sebesar $60,60 \%$ dan waktu kontak selama 2 menit, sebesar 89,48\%. Berdasarkan persentase rata-rata penurunan angka kuman maka waktu kontak yang efektif adalah 2 menit dan memenuhi syarat kesehatan yaitu dibawah dari 100 koloni $/ \mathrm{cm}^{2}$ dengan rata-rata penurunan angka kuman 52 koloni/ $\mathrm{cm}^{2}$.

Berdasarkan tujuan untuk mengetahui adanya perbedaan penurunan angka kuman dengan variasi waktu kontak larutan air jeruk nipis maka dilakukan uji statistik menggunakan one way anova. Data yang diperoleh berdistribusi normal dan homogen atau variasi sama sehingga dapat dilakukan uji one way anova dan dilanjutkan dengan uji LSD.

Berdasarkan uji One Way Anova $\mathrm{P}_{\text {value }} 0,016<$ nilai $\alpha 0,05$ yang berarti bahwa $\mathrm{H}_{0}$ ditolak dan $\mathrm{H}_{\mathrm{a}}$ diterima yaitu persentase penurunan angka kuman memiliki perbedaan yang signifikan terhadap variasi waktu kontak larutan air jeruk nipis (1 menit, 1,5 menit dan 2 menit). Waktu kontak dari terbesar ke yang terkecil yang diurutkan dari uji $L S D$ adalah 2 menit $>1,5$ menit $=1$ menit.

Terdapat peningkatan persentase penurunan angka kuman 2 menit $>1,5$ menit > 1 menit. Hal ini menunjukkan bahwa semakin lama waktu pemaparan 
terhadap desinfektan, makin besar daya bunuh kuman. Tetapi hal ini tidak berlaku terhadap desinfektan tingkat rendah karena berapa lama waktu pemaparan yang dilakukan, hanya mampu membunuh mikroorganisme tertentu sesuai dengan kemampuannya[9].

Berdasarkan uji LSD 2 menit memiliki perbedaan yang signifikan dengan 1 menit dan 1,5 menit. Waktu kontak 1 menit dan 1,5 menit memiliki selisih rata-rata persentase penurunan yang rendah yaitu hanya mencapai $5,99 \%$. Selisih rata-rata persentase penurunan 2 menit dengan 1 menit sebesar $34,87 \%$ dan selisih rata-rata persentase penurunan 2 menit dengan 1,5 menit sebesar 28,88\%. Maka waktu kontak 2 menit memiliki perbedaan signifikan jika dibandingkan antara 1 menit dengan 1,5 menit yang tidak memiliki perbedaan signifikan atau sama.

Penyebab tidak terdapat perbedaan yang signifikan antara waktu kontak 1 menit dengan 1,5 menit karena kemungkinan adanya perbedaan jenis bakteri dan karakteristik bakteri yang tumbuh. Salah satu zat antibakteri yang terkandung dalam air jeruk nipis adalah flavonoid. Flavonoid adalah senyawa polar, kepolaran ini menyebabkan senyawa lebih mudah menembus dinding sel bakteri seperti $S$. aureus karena dinding sel bakteri ini berlapis tunggal dan tersusun atas peptidoglikan (protein dan gula) serta lipid dengan kadar (1-4\%). Senyawa polar sulit menembus dinding sel yang berlapis tiga tersusun atas peptidoglikan dan lipid[10]. Sehingga memerlukan waktu yang lebih lama untuk menembus dinding sel yang tersusun sel 3 lapis daripada sel yang berlapis tunggal.

Dalam hal ini waktu kontak 1 menit dengan 1,5 menit memiliki jarak waktu yang pendek yaitu hanya 0,5 menit sehingga penurunan angka kuman hanya sedikit yaitu 5,99\%. Berdasarkan hasil pemeriksaan bahwa angka kuman sebelum perlakuan waktu kontak 1,5 menit memiliki rata-rata angka kuman lebih tinggi dibandingkan dengan waktu kontak 1 menit dan 2 menit sehingga memerlukan waktu yang lebih lama untuk proses desinfeksi. Faktor yang berpengaruh terhadap aktivitas desinfektan adalah jumlah mikroorganisme yang terdapat pada benda yang akan didesinfeksi.

Waktu kontak 1 menit akan memenuhi standar angka kuman sebesar 100 koloni/ $\mathrm{cm}^{2}$ apabila memiliki angka kuman maksimal $220 \mathrm{koloni} / \mathrm{cm}^{2}$. Waktu kontak 1,5 menit akan memenuhi standar angka kuman apabila memiliki angka kuman maksimal $254 \mathrm{koloni} / \mathrm{cm}^{2}$ dan waktu kontak 2 menit maksmial memiliki angka kuman 951 koloni/ $\mathrm{cm}^{2}$ agar angka kuman dapat memenuhi standar.

\section{KESIMPULAN DAN SARAN}

Air jeruk nipis (Citrus aurantifolia Swingle) dapat menurunkan angka kuman karena memiliki perbedaan yang signifikan sebelum dan sesudah perlakuan. Keberadaan E. coli sebelum dan sesudah perlakuan negatif (-). Terdapat perbedaan yang signifikan terhadap penurunan angka kuman sesudah perlakuan dengan variasi waktu kontak 1 menit, 1,5 menit dan 2 menit menggunakan desinfektan larutan air jeruk nipis $10 \%$. Variasi waktu kontak yang efektif dengan desinfeksi menggunakan larutan air jeruk nipis (Citrus aurantifolia Swingle) 10\% adalah 2 menit dengan persentase penurunan angka kuman sebesar 89,48\%. Jeruk nipis dapat digunakan sebagai desinfektan alami dengan waktu kontak untuk perendaman minimal 2 menit dan harus memperhatikan kebersihan pada proses pencucian.

Diharapkan kepada peneliti selanjutnya dapat melakukan pengembangan dari penelitian ini seperti membuat alat pengatur konsentrasi larutan air jeruk nipis (Citrus aurantifolia Swingle) konsentrasi $10 \%$ agar lebih efektif dan efisien untuk diaplikasikan di masyarakat.

\section{KEPUSTAKAAN}

1. Andargie, G., Kassu, A., Moges, F., Tiruneh, M., \& Huruy, K. 2008. Prevalence of Bacteria and Intestinal Parasites among Food-handlers in 
Gondar town. North West Ethiopia. J. Health Popul Nutr; 26 (4):451455.International Centre For Diarhoeal. Bangladesh: Disease Research.

2. Badan Pengawas Obat dan Makanan. Laporan Tahunan Badan POM RI Tahun 2014. Jakarta: BPOM.

3. Kemendikbud. 2013. Keamanan Pangan. Jakarta.

4. Adam, M. \& Moetarjemi, Y. 2004. Dasar-Dasar Keamanan Makanan untuk Petugas Kesehatan. Jakarta: EGC.

5. Notoatmodjo. 2010. Metodelogi Penelitian Kesehatan. Jakarta: Rineka Cipta.

6. Berlian, Zainal, Awalul, F., Eka A 2016. Penggunaan Perasan Jeruk Nipis (Citrus aurantifolia) Dalam Menghambat Bakteri Escherichia coli Pada Bahan Pangan. Jurnal Bioilmi Vol. 2 No. 1 hal 55.

7. Hudri, F. A. 2014. Uji Efektivitas Ekstrak Madu Multiflora Dalam Menghambat Pertumbuhan Bakteri Salmonella typhi. Jakarta: UIN Syarif Hidayatullah. Skripsi.
8. Astarini, Niluh Putu Febrina., Perry Burhan, Yulfi Zetra. 2010. Minyak Atsiri dari Kulit Buah Citrus grandis, Citrus aurantium (L.) dan Citrus aurantifolia (Rutaceae) Sebagai Senyawa Antibakteri dan Insektisida: Prosiding Skripsi Semester Genap 2009/2010 SK-091304. Jurusan Kimia: Institut Teknologi Sepuluh Nopember

9. Yalina, Sukma. 2014. Efektivitas Desinfektan Pine Oil 1,5\% + Creasylic Acid dan Pine Oil 2,5\% Terhadap Jumlah Angka Kuman Pada Lantai Ruang Rawat Inap Rumah Sakit Umum Deli Medan 2013. Fakultas Kesehatan Masyarakat: Universitas Sumatera Utara. Skripsi

10. Lathifah, Q. A. 2008. Uji Efektivitas Ekstrak Kasar Senyawa Antibakteri Pada Buah Belimbing Wuluh (Averrhoa blimbi L.) dengan Variasi Pelarut. Malang: Universitas Islam Negeri Malang.Skripsi. 